\title{
Use of Deviations of Purchasing Power Parity and Interest Rate Parity to Clarify the 1997 Asian Financial Crisis
}

\author{
Mao-Wei Hung \\ Department of International Business, National Taiwan University, Taiwan \\ Yin-Ching Jan \\ Department of Industrial Engineering and Management, \\ National Chin-Yi Institute of Technology, Taiwan
}

This study is an attempt to examine whether the deviations of purchasing power parity and uncover interest rate parity Granger-cause the 1997 Asian financial crisis by using vector autoregression and Granger causality tests. The results show that the purchasing power parity and uncover interest rate parity do not hold for most Asian markets. We find weak evidence to support that the deviations of purchasing power parity and uncover interest rate parity have the power to explicate the origin of the financial crisis.

Keywords: Financial crisis; Granger causality; Interest rate parity; Purchasing power parity; Vector autoregression.

\section{Introduction}

In this paper, we use deviations of purchasing power parity (PPP) and uncover interest rate parity (UIP) to clarify the 1997 Asian financial crisis. The crisis threatened investors worldwide, because all the economic indicators appeared positive for most Asian markets before the crisis. Although prices of the Asian financial markets have rebounded to their pre-crisis levels, the financial crisis had a significant effect on social welfare and governmental

\footnotetext{
We are grateful to Shi-Kuan Chen and seminar participants at the Cause and Remedies of Asian Crisis Conference (November 1999) in National Taiwan University for helpful comments. We also thank the editor and an anonymous referee for helpful comments and suggestions. We acknowledge the financial support of the National Science Council of the Republic of China (NSC 87-2416-H-002-007- E24). Corresponding author: Yin-Ching Jan, e-mail: jan511@chinyi.ncit.edu.tw.
} 
economic polices. In order to prevent Asian markets from a similar future crisis, we need to understand the origin of the financial crisis in more detail.

Researchers had provided many empirical explanations for the origin of the financial crisis. ${ }^{1}$ The promising factors include large appreciation of the real exchange rate (e.g., Frankel and Rose, 1996, and Sachs et al., 1996), low levels of foreign exchange reserves (e.g., Radelet and Sachs, 1998a, and Sachs et al., 1996), weak banking system (e.g., Corsetti et al., 1998a, and Sachs et al. 1996), low ratio of foreign direct investment to debt (e.g., Frankel and Rose, 1996, and Radelet and Sachs, 1998b), moral hazard (e.g., Corsetti et al., 1998b), and price bubbles (e.g., Basile and Joyce, 1998, and Edison et al., 1998). Most studies examined the influence of macroeconomic variables on the financial crisis, but the macroeconomic variables themselves may be affected by other omitted variables. For example, Edwards (1999) have argued that overvalued currency deteriorated current accounts, if the central bank raised interest rate to attract foreign funds, the high interest rate would increase the cost of capital and mount non-performing banking loans. Thus, only the use of some macroeconomic variables to explain the financial crisis may suffer from spurious relation.

This study is an attempt to examine whether the deviations of PPP and UIP have the power to explain the cause of the Asian financial crisis. If the UIP does not hold in Asian markets, and if the expected returns in Asian markets are higher than in other markets, international capital flows may pour into the Asian markets. For example, Frankel and Okongwu (1995) pointed out that the differential interest rate between Asia and the U.S. resulted in large capital flows into Asian markets. Relative PPP implies that international expected inflation gap equals to the expected percentage change in the exchange rate. If the macroeconomic factors force upsetting the PPP relationship is nominal, this will have only a transitory effect on the deviations from PPP. See, e.g., Bayoumi and MacDonald (1999). Therefore, real exchange rate may exist as a mean-reverting property, which can be used to forecast the expected percentage change in the exchange rate. Chinn (1998) used the equilibrium of PPP to evaluate whether the Asian currencies were overvalued or undervalued. Either overvalued or undervalued currencies may result in capital flows pouring into or out of the Asian markets.

When the exchange rate does not fully reflect the variations of capital flows owing to the pegged or managed exchange rate regime, the poured

\footnotetext{
${ }^{1}$ See Kaminsky et al. (1998) and Nixson and Walters (1999) for more detailed survey of that literature.
} 
capital inflow may increase the market's price and inflation. ${ }^{2}$ If a country's foreign reserve is low, then the country is vulnerable to a short-term capital outflow or currency attack. The factors that cause the crisis may be due to the low foreign reserve and capital flight, but the origin is the deviations of PPP and UIP.

To test our hypothesis, we used vector autoregression (VAR) and the Granger causality test to examine whether the deviations of PPP and UIP Granger-cause the Asian financial crisis. The result shows that the PPP and UIP do not hold for most Asian markets. We find weak evidence that the deviations of PPP and UIP have the power to explain the cause of the Asian financial crisis. Under low transaction cost and more integrated financial market, exchange rates might not fully reflect the variations of inflation rate and interest rate with respect to other markets within the fixed or pegged exchange regime. This may result in a large variation of international capital flow, which provides a trigger for the Asian financial crisis. The result suggests that the fixed or pegged exchange rate regime is difficult to maintain under integrated markets.

This paper proceeds as follows. We describe how to construct data in the next section. Then, we describe the methodology and present the empirical results. Finally, the conclusions are made.

\section{Data Composition}

Most of our data set derives from the International Financial Statistics (IFS) of the International Monetary Fund (IMF). It consists of quarterly observations from spring 1970 to summer 1998 for ten Asian markets. These include China, Hong Kong, Indonesia, Japan, South Korea, Malaysia, the Philippines, Singapore, Taiwan, and Thailand. A more detailed data source, description, and period can be found in the Appendix.

\subsection{The financial crisis index}

We follow Corsetti et al. (1998a), Frankel and Rose (1996), Radelet and Sachs (1998a), and Sachs et al. (1996) to construct two financial crisis indices. The first uses the rate of variation of exchange rate and foreign reserve to compile indicator variables separately. Then we average the two indicator variables, i.e.,

$$
C I 1_{t}=\left(E X I_{t}+F A I_{t}\right) / 2
$$

\footnotetext{
${ }^{2}$ This is a viewpoint of self-fulfilling, see, e.g., Cole and Kehoe $(1996,1998)$.
} 
where $C I 1_{t}$ is the first financial crisis index at time $t$,

$$
\begin{aligned}
& E X I_{t}=\left\{\begin{array}{rr}
0, & E X_{t} \leq 0 \\
1, & 0<E X_{t} \leq 5 \% \\
2, & 5 \%<E X_{t} \leq 10 \% \\
3, & 10 \%<E X_{t} \leq 15 \% \\
4, & 15 \%<E X_{t} \leq 20 \% \\
5, & E X_{t}>20 \%
\end{array}, \quad F A I_{t}=\left\{\begin{array}{rr}
0, & F A C_{t} \geq 0 \\
1, & 0>F A C_{t} \geq-5 \% \\
2, & -5 \%>F A C_{t} \geq-10 \% \\
3, & -10 \%>F A C_{t} \geq-15 \% \\
4, & -15 \%>F A C_{t} \geq-20 \% \\
5, & F A C_{t}<-20 \%
\end{array}\right.\right. \\
& E X_{t}=\left(S-S_{t-1}\right) / S_{t-1}, \quad F A C_{t}=\left(F A_{t}-F A_{t-1}\right) / F A_{t-1} \text {, }
\end{aligned}
$$

$S_{t}$ is the nominal exchange rate relative to the U.S. dollar at time $t$, expressed as the local currency/U.S. dollar, and $F A_{t}$ is the foreign reserve at time $t$.

The definition of the second financial crisis index is the same as the work of Sachs et al. (1996), which is a weighted average of the percent change in foreign reserves and the percent change of exchange rate with respect to the U.S. dollar. In order to make the same volatility for the two series, the weights are given by the relative variation of each series over the sample period. The difference between the first financial crisis index and the second is that the first is a staged function, which captures the idea that a crisis may increase only when these two variables exceed a certain threshold value.

The behavior of these two crisis indices can be seen in Figs. 1 and 2 . Of the ten markets, four markets (Indonesia, Malaysia, the Philippines, and Thailand) do not allow free flow of funds during the sample period. ${ }^{3}$ However, they cannot rule out the financial crisis. We can see that these four markets have a very serious financial crisis index in 1997 and 1998. The unconditional correlations of these two financial crisis indices are displayed in Table 1. Panel A demonstrates the correlations of the first crisis index. Most markets show strong correlations with each other except China and Hong Kong. The crisis index of China shows no correlation with other markets except a correlation of -0.195 with Hong Kong. Hong Kong has a correlation of 0.211 with Taiwan, and shows no significant correlation with other remaining markets. The correlations of the second crisis index showed in panel B are very similar to the first. China does not have any correlation with other markets except a correlation of 0.204 with Hong Kong. Hong

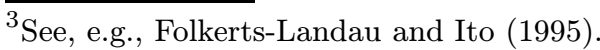


Use of PPP \& UIP Deviations to Clarify 1997 Asian Financial Crisis • 199
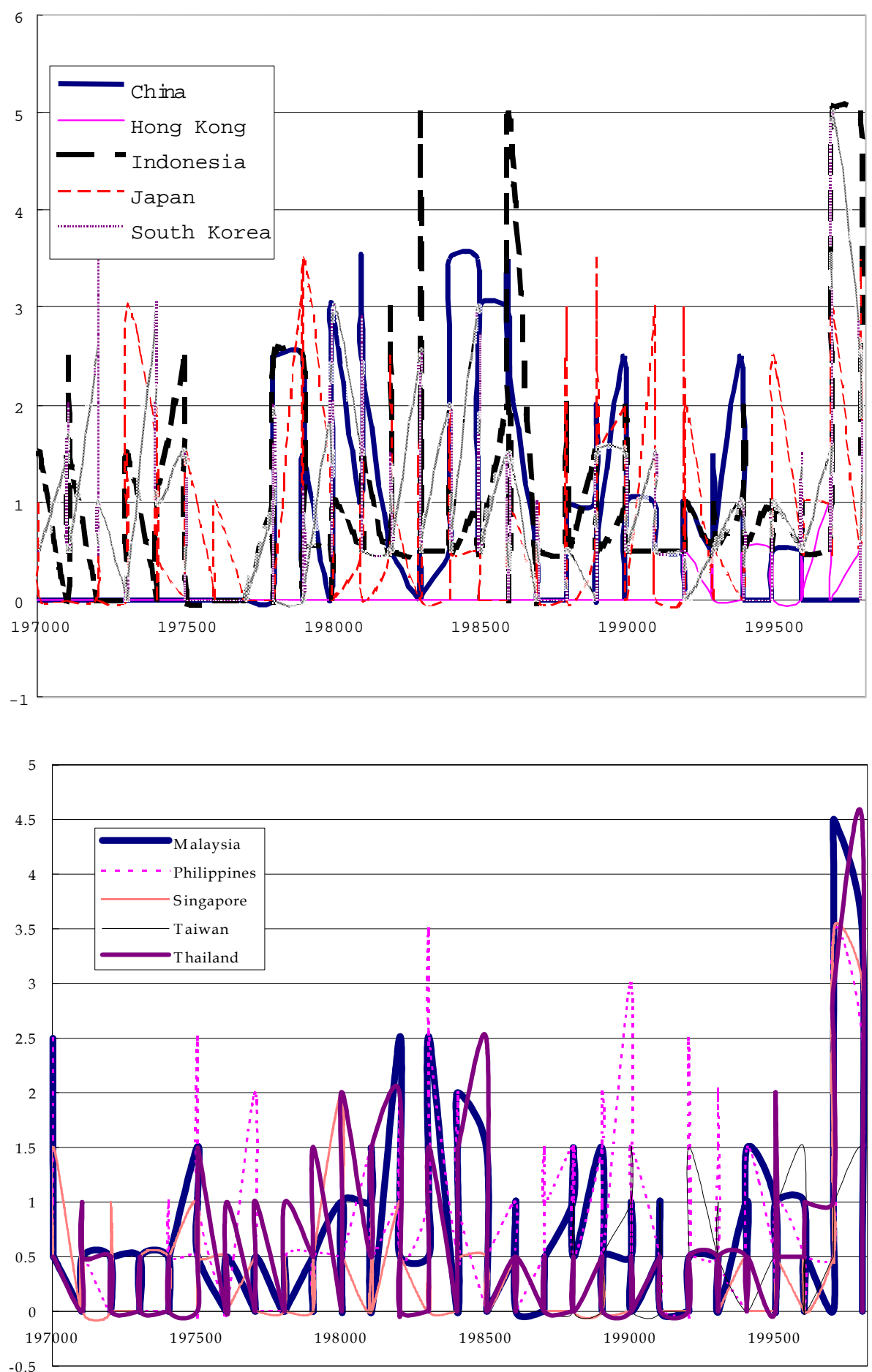

Fig. 1. First Financial Crisis Index 
200 • Mao-Wei Hung \& Yin-Ching Jan
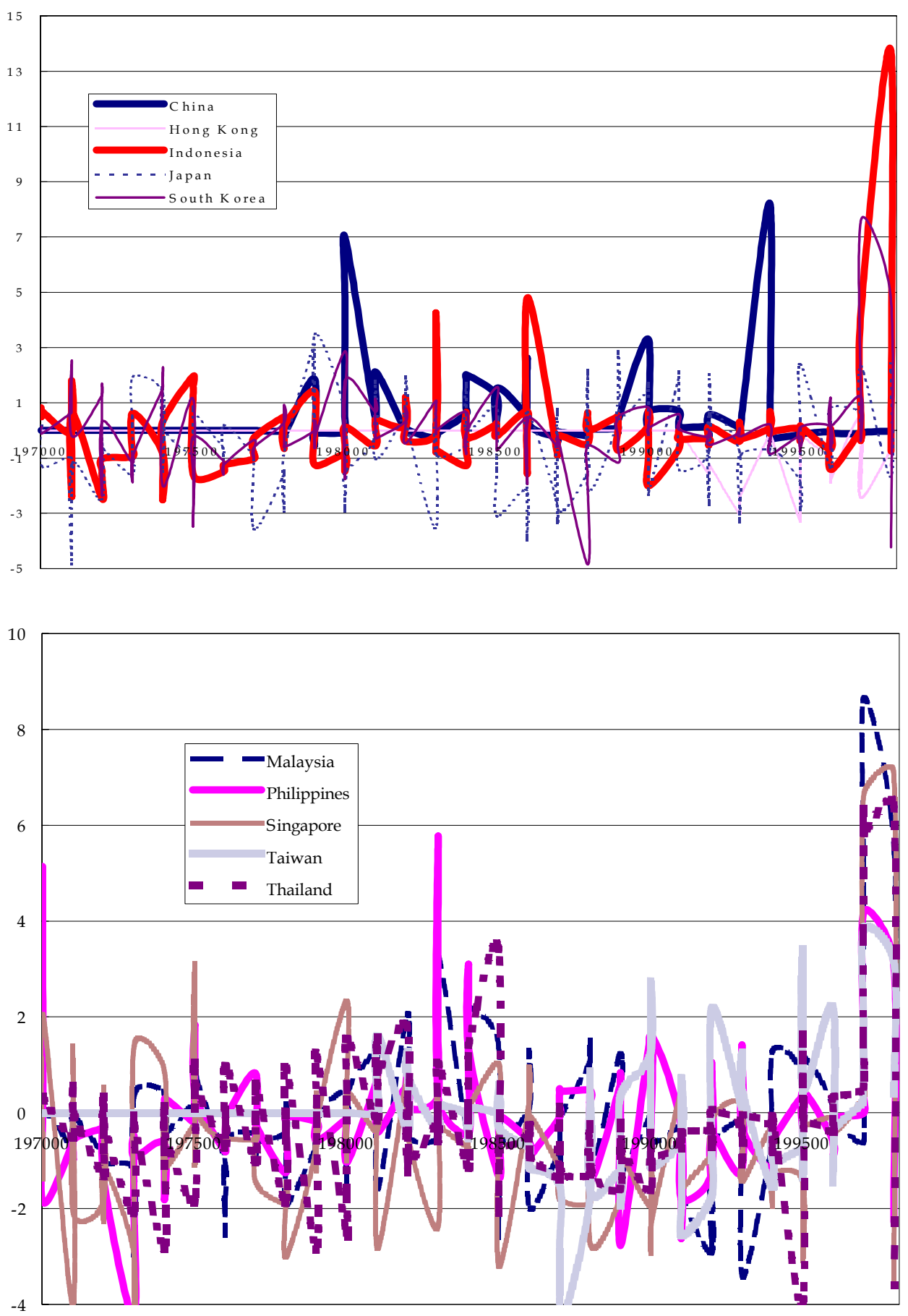

Fig. 2. Second Financial Crisis Index 
Table 1. Correlations of the Financial Crisis Indices

Panel A. Correlations of the first crisis indices

\begin{tabular}{|c|c|c|c|c|c|c|c|c|c|}
\hline Market & $\begin{array}{l}\text { Hong } \\
\text { Kong }\end{array}$ & Indonesia & Japan & $\begin{array}{l}\text { South } \\
\text { Korea }\end{array}$ & Malaysia & Philippines & Singapore & Taiwan & Thailand \\
\hline China & -0.195 & 0.062 & -0.025 & 0.095 & -0.060 & -0.097 & -0.043 & -0.051 & 0.080 \\
\hline Hong Kong & H.K. & 0.049 & 0.121 & -0.069 & -0.065 & -0.071 & 0.031 & 0.211 & -0.010 \\
\hline Indonesia & & Indonesia & 0.247 & 0.274 & 0.447 & 0.325 & 0.496 & 0.474 & 0.346 \\
\hline Japan & & & Japan & 0.064 & 0.149 & 0.263 & 0.239 & 0.290 & 0.157 \\
\hline South Korea & & & & S. Korea & 0.337 & 0.123 & 0.517 & 0.270 & 0.301 \\
\hline Malaysia & & & & & Malaysia & 0.540 & 0.528 & 0.412 & 0.606 \\
\hline Philippines & & & & & & Philippines & 0.346 & 0.166 & 0.345 \\
\hline Singapore & & & & & & & Singapore & 0.381 & 0.564 \\
\hline Taiwan & & & & & & & & Taiwan & 0.302 \\
\hline Thailand & & & & & & & & & Thailand \\
\hline
\end{tabular}


Table 1. (continued) Correlations of the Financial Crisis Indices

\begin{tabular}{|c|c|c|c|c|c|c|c|c|c|}
\hline Market & $\begin{array}{l}\text { Hong } \\
\text { Kong }\end{array}$ & Indonesia & Japan & $\begin{array}{l}\text { South } \\
\text { Korea }\end{array}$ & Malaysia & Philippines & Singapore & Taiwan & Thailand \\
\hline China & 0.204 & -0.036 & -0.037 & 0.038 & -0.032 & -0.076 & 0.003 & -0.005 & 0.059 \\
\hline Hong Kong & H.K. & 0.086 & 0.321 & -0.070 & 0.040 & -0.201 & 0.048 & 0.074 & 0.098 \\
\hline Indonesia & & Indonesia & 0.116 & 0.362 & 0.455 & 0.330 & 0.534 & 0.359 & 0.417 \\
\hline Japan & & & Japan & 0.032 & 0.231 & 0.164 & 0.282 & 0.269 & 0.067 \\
\hline South Korea & & & & S. Korea & 0.434 & 0.227 & 0.576 & 0.398 & 0.404 \\
\hline Malaysia & & & & & Malaysia & 0.548 & 0.647 & 0.418 & 0.585 \\
\hline Philippines & & & & & & Philippines & 0.380 & 0.221 & 0.375 \\
\hline Singapore & & & & & & & Singapore & 0.498 & 0.540 \\
\hline Taiwan & & & & & & & & Taiwan & 0.384 \\
\hline Thailand & & & & & & & & & Thailand \\
\hline \multicolumn{10}{|c|}{ Panel C. Correlations of the first and second crisis index } \\
\hline China & $\begin{array}{l}\text { Hong } \\
\text { Kong }\end{array}$ & Indonesia & Japan & $\begin{array}{l}\text { South } \\
\text { Korea }\end{array}$ & Malaysia & Philippines & Singapore & Taiwan & Thailand \\
\hline 0.604 & 0.304 & 0.820 & 0.845 & 0.795 & 0.907 & 0.805 & 0.842 & 0.851 & 0.830 \\
\hline
\end{tabular}


Kong shows a correlation of 0.321 with Japan, and does not correlate with any other markets. Panel $\mathrm{C}$ shows very strong correlations for these two crisis indices. Most markets present a correlation of more than 0.604, except a correlation of 0.304 in Hong Kong.

\subsection{The deviations of PPP and UIP}

The PPP equate the change rate of exchange rate to the differential of two country's inflation rates. This relation can be written approximately as:

$$
E_{t}\left[\ln \left(\pi_{t+1}^{h}\right)\right]-E_{t}\left[\ln \left(\pi_{t+1}^{f}\right)\right]=E_{t}\left[\ln \left(S_{t+1} / S_{t}\right)\right],
$$

where $E_{t}[\bullet]$ is an expectation function at time $t$,

$\ln (\bullet)$ is a natural logarithmic function,

$\pi_{t+1}$ is the inflation rate from time $t$ to $t+1$, and superscripts $h$ and $f$ represent the home country and the U.S., respectively.

The deviation of PPP $(P D)$ is calculated by the difference of the change rate of exchange rate and the differential of two country's inflation rates, i.e.,

$$
P D_{t+1}=\left(\ln \pi_{t+1}^{h}-\ln \pi_{t+1}^{f}\right)-\ln \left(S_{t+1} / S_{t}\right) .
$$

A negative purchasing power parity deviation represents that the purchasing power in Asia markets is stronger than in the U.S. As a result, international capital may flow into Asian regions.

The UIP specifies a relationship between the relative interest rates of two markets and their exchange rates. This relation can be written as follows:

$$
E_{t}\left(S_{t+1} / S_{t}\right)=\ln \left(1+i_{t}^{h}\right)-\ln \left(1+i_{t}^{f}\right)
$$

where $i_{t}^{h, f}$ is the interest rate from time $t$ to $t+1$, and superscripts $h$ and $f$ represent the home country and the U.S.

The deviation of UIP $(I D)$ is defined as the difference of the change rate of exchange rate and the differential of two country's interest rate, i.e., ${ }^{4}$

$$
I D_{t+1}=\left(\ln \left(S_{t+1} / S_{t}\right)-\ln \left(1+i_{t}^{h}\right)-\ln \left(1+i_{t}^{f}\right)\right) .
$$

A negative deviation of UIP displays an arbitrary opportunity in investing in Asia.

\footnotetext{
${ }^{4}$ There is a caveat that the deviation of UIP, which is the difference between the exchange rate and interest rate differential, may suffer from the risk embedded in different markets.
} 


\section{Methodology and Empirical Results}

\subsection{The examination of PPP and UIP}

There are many methods to examine the existence of PPP and UIP. Early studies estimated regression model of exchange rate (or interest rate) on the inflation rate. The estimated regression coefficients are then used to test the null hypotheses of the existence of PPP and UIP. However, Goodwin and Grennes (1994) showed that transaction costs might bias the regression coefficients. As a result, some researchers applied unit root test and cointegration test to avoid this bias, e.g., Chinn and Frankel (1995) and Goodwin and Grennes (1994). Accordingly, we use unit root test to examine the existence of PPP and UIP. For PPP to exist, Equation (2) must hold. Under rational expectation, Equation (2) becomes:

$$
\ln \left(\frac{S_{t+1}}{S_{t}} \times \frac{\pi_{t+1}^{f}}{\pi_{t+1}^{d}}\right)=\varepsilon_{t+1},
$$

where $\varepsilon_{t+1}$ is an error term. If PPP holds, $\varepsilon_{t+1}$ follows a stationary process. Hence, we can apply unit root test to examine whether the error term displays the stationary property.

If UIP holds, under rational expectation, Equation (4) becomes:

$$
\ln \left(\frac{S_{t+1}}{S_{t}} \times \frac{1+i_{t}^{f}}{1+i_{t}^{h}}\right)=\mu_{t+1},
$$

where the error term $\mu_{t+1}$ has to display a stationary process. So we can test the existence of UIP by unit root test.

Table 2 displays Augmented Dickey-Fuller (ADF) tests of null hypotheses of a unit root existing in each country with respect to the U.S. For the tests of PPP, three markets (Indonesia, Japan, and the Philippines) reach 5\% significance level. Other markets cannot reject the null hypothesis of a unit root in Equation (6). In other words, the results show that the PPP does not hold on a quarterly basis in most Asian markets. For the tests of UIP, Indonesia, Malaysia, Singapore, and Thailand markets reject the unit root of error term in Equation (7). The results again show that the variations of exchange rate cannot fully reflect the differential of some Asian market's interest rate relative to the U.S. under an open market policy.

\subsection{The adequacy of crisis index}

The construction of the financial crisis indices must reflect the fact that it has a significant impact on economies. Only the depreciation of currency or 
Table 2. The Unit Root Tests of Purchasing Power Parity and Uncover Interest Rate Parity*

\begin{tabular}{lcccc}
\hline & \multicolumn{2}{c}{ Purchasing power parity } & \multicolumn{2}{c}{ Uncover interest rate parity } \\
\hline \multicolumn{1}{c}{ Markets } & Lags & ADF & Lags & ADF \\
\hline China & 0 & -1.303 & 0 & -0.946 \\
Hong Kong & 0 & -1.004 & 7 & -1.312 \\
Indonesia & 0 & $-4.754^{* *}$ & 0 & $-3.647^{* *}$ \\
Japan & 0 & $-3.852^{* *}$ & 1 & -2.371 \\
South Korea & 2 & -1.603 & 0 & -2.282 \\
Malaysia & 3 & -1.681 & 0 & $-3.790^{* *}$ \\
Philippines & 0 & $-3.461^{* *}$ & 1 & -2.657 \\
Singapore & 3 & -2.394 & 0 & $-4.004^{* *}$ \\
Taiwan & 0 & -3.041 & 0 & -3.944 \\
Thailand & 3 & -2.536 & 0 & $-3.627^{* *}$ \\
\hline
\end{tabular}

${ }^{*}$ The unit root tests are conducted by Augmented Dickey-Fuller (ADF) test with constant and trend. The choice of lags is based on BIC criteria. This routine is written by Norman Morin, and is posted on the Estima website. We are responsible for any errors. ${ }^{* *}$ denotes significance at $5 \%$ level.

the plummet of foreign reserves cannot be regarded as a financial crisis if there are no influences on the economies. The initiations of most financial crisis result from a large amount of capital outflow. The central bank always raises interest rate to prevent capital flight. A high interest rate may injure the economy of any country. Therefore, there is a relationship between the financial crisis and economic growth.

To investigate the adequacy of the constructed financial crisis indices, we apply a regression model to examine the relationship between the financial crisis indices and economic growth. The results are shown in Table 3. In the first financial crisis index, most regression coefficient estimates reach $5 \%$ significant level and most coefficients of determination over $15 \%$ except Hong Kong. All the signs of coefficients are negative, showing the negative relation between the first financial crisis index and economic growth. In the second financial crisis index, the regression coefficients of Hong Kong and Malaysia cannot reach 5\% significance level. Moreover, their related coefficients of determination are negative. This might result from the fact that Hong Kong's currency board raised interest rates to repel currency attacks successfully. Therefore, the financial crisis indices could not reflect the financial crisis in Hong Kong. 
Table 3. The Relationship between Financial Crisis Index and Economic Growth* We estimate a regression model of financial crisis index $(C I)$ with economic growth rate $(\Delta G D P)$ as follows: $\Delta G D P_{t+1}=\beta_{0}+\beta_{1} C I_{t}+\varepsilon_{t}$.

\begin{tabular}{lcccc}
\hline & \multicolumn{2}{c}{ First financial crisis index } & \multicolumn{2}{c}{ Second financial crisis index } \\
\hline \multicolumn{1}{c}{ Markets } & $\beta_{1}$ & $\bar{R}^{2}$ & $\beta_{1}$ & $\bar{R}^{2}$ \\
\hline China & $\mathrm{NA}$ & $\mathrm{NA}$ & $\mathrm{NA}$ & $\mathrm{NA}$ \\
Hong Kong & $-0.087(0.096)$ & $-1.65 \%$ & $0.005(0.028)$ & $-9.67 \%$ \\
Indonesia & $-0.048(0.004)^{* *}$ & $57.17 \%$ & $-0.037(0.004)^{* *}$ & $43.84 \%$ \\
Japan & $-0.043(0.013)^{* *}$ & $15.41 \%$ & $-0.029(0.007)^{* *}$ & $23.29 \%$ \\
South Korea & $-0.072(0.020)^{* *}$ & $17.98 \%$ & $-0.055(0.014)^{* *}$ & $22.64 \%$ \\
Malaysia & $-0.120(0.053)^{* *}$ & $32.02 \%$ & $-0.033(0.039)$ & $-3.21 \%$ \\
Philippines & $-0.058(0.014)^{* *}$ & $34.54 \%$ & $-0.042(0.007)^{* *}$ & $50.27 \%$ \\
Singapore & $-0.072(0.018)^{* *}$ & $36.00 \%$ & $-0.026(0.006)^{* *}$ & $45.37 \%$ \\
Taiwan & $-0.031(0.010)^{* *}$ & $16.68 \%$ & $-0.012(0.003)^{* *}$ & $34.84 \%$ \\
Thailand & $-0.072(0.010)^{* *}$ & $48.79 \%$ & $-0.030(0.004)^{* *}$ & $54.02 \%$ \\
\hline
\end{tabular}

${ }^{*}$ The data of gross domestic production is not available (NA) in China. The value in the parentheses is a consistent estimate of standard error allowing for heteroscedasticity. $\bar{R}^{2}$ is adjusted coefficient of determination. ${ }^{* *}$ denotes significance at $5 \%$ level.

\subsection{The Granger causality test}

The application of the Granger causality tests in economics has proliferated. The Granger causality test examines whether past changes in one variable, $x$, help to explain current changes in another variable, $y$, over and above the explanation provided by past changes in $y$. If no, then one can conclude that $x$ does not Granger-cause $y$. The Granger causality test is based on the following regression:

$$
\Delta y_{t}=\sum_{i=1}^{k} \beta_{i} \Delta y_{t-i}+\sum_{j=1}^{l} \gamma_{j} \Delta x_{t-j}+\xi_{t},
$$

where $\Delta$ denotes the first-difference operator and makes the variables in Equation (8) stationary, $\beta_{i}$ and $\gamma_{j}$ are parameters, and $\xi_{t}$ is white noise. Based on Equation (8), the null hypothesis that $x$ does not Granger-cause $y$ is rejected if all $\gamma_{j}$ are jointly significant. In this study, $y$ is our constructed financial crisis index, and the explanatory variables $x$ include not only deviations of PPP and UIP, but also other variables which had been proved to have some explanatory power by most researchers. The explanatory variables include the ratio of money supply (M2) to foreign reserves, the ratio of lending boom to gross domestic production (GDP), the ratio of current 
account to GDP, the ratio of capital account to GDP, the ratio of foreign debt to GDP, and real exchange rate with respect to the U.S.

Panel $\mathrm{A}$ in Table 4 displays the results of testing the first financial crisis index. The M2/foreign reserves reach 5\% significance level in Indonesia, Japan, Malaysia, Taiwan, and Thailand. The ratios of the lending boom to GDP Granger-cause the first financial crisis only in South Korea. The ratios of current account to GDP impact the first financial crisis significantly only in Indonesia, while the ratios of capital account to GDP cannot reach conventional significance level in our sample. The ratios of foreign debt to GDP significantly Granger-cause the first financial crisis in Indonesia, South Korea, Singapore, and Thailand. The real exchange rate in Indonesia, Japan, South Korea, Malaysia, and the Philippines significantly influence the first financial crisis. The deviations of PPP reach significance at the $5 \%$ level in Japan, South Korea, Taiwan, and Thailand. The deviations of UIP reach significance at the $5 \%$ level in Indonesia, Japan, South Korea, the Philippines, and Thailand.

The results of testing Granger causality for the second financial crisis index are shown in panel B of Table 4 . The results are similar to those of the first financial crisis index. The M2/foreign reserves reach a $5 \%$ significance level in Indonesia, Japan, Malaysia, the Philippines, Singapore, Taiwan, and Thailand. The ratios of the lending boom to GDP cannot Granger-cause the second financial crisis significantly in our sample. The ratios of current account to GDP have an impact on the second financial crisis significantly in South Korea and Thailand. The ratios of capital account to GDP are found to be significant only in Indonesia. The ratios of foreign debt to GDP significantly Granger-cause the second financial crisis in Indonesia, South Korea, and Singapore. The real exchange rates in Indonesia, Japan, South Korea, Malaysia, the Philippines, Singapore, and Thailand significantly influence the second financial crisis. The deviations of PPP are significant in Japan, South Korea, Malaysia, Singapore, and Thailand. The deviations of UIP are significance in Japan, Malaysia, the Philippines, and Thailand.

All the estimates are positive in either the first or second financial crisis index, implying that increasing any explanatory variables would increase the financial crisis index. Of all the variables examined, the M2/foreign reserve, foreign debt/GDP, real exchange rate, and the deviations of PPP and UIP have more explanatory power than other variables. Except the deviations of PPP and UIP, the others had been proved to have a significant influence on the financial crisis, e.g., Frankel and Rose (1996), Kaminsky and 
Table 4. Granger Causality Tests

We estimate equation: $\Delta y_{t}=\sum_{i=1}^{k} \beta_{i} \Delta y_{t-i}+\sum_{j=1}^{l} \gamma_{j} \Delta x_{t-j}+\mu_{t}$, and test the null hypothesis of parameters $\gamma_{j}=0$ for all $j$. We set lags $k=l$, the value of lags $l$ is based on $\mathrm{BIC}$ criteria and appeared in the parentheses.

Panel A. First Financial Crisis Index

\begin{tabular}{|c|c|c|c|c|c|c|c|c|}
\hline Markets & $\begin{array}{l}\text { M2/Foreign } \\
\text { Reserve }\end{array}$ & $\begin{array}{l}\text { Lending } \\
\text { Boom/ } \\
\text { GDP }\end{array}$ & $\begin{array}{c}\text { Current } \\
\text { Account } \\
\text { GDP }\end{array}$ & $\begin{array}{c}\text { Capital } \\
\text { Account } \\
\text { GDP }\end{array}$ & $\begin{array}{l}\text { Foreign } \\
\text { Debt/GDP }\end{array}$ & $\begin{array}{c}\text { Real } \\
\text { Exchange } \\
\text { Rate }\end{array}$ & $\begin{array}{c}\text { Deviation } \\
\text { of PPP }\end{array}$ & $\begin{array}{c}\text { Deviation } \\
\text { of UIP }\end{array}$ \\
\hline China & NA & NA & NA & NA & NA & $\begin{array}{c}(1) \\
1.712\end{array}$ & $\begin{array}{c}(1) \\
0.030\end{array}$ & $\begin{array}{c}(1) \\
0.046\end{array}$ \\
\hline $\begin{array}{l}\text { Hong } \\
\text { Kong }\end{array}$ & $\begin{array}{c}(1) \\
1.841\end{array}$ & $\begin{array}{c}(1) \\
0.386\end{array}$ & NA & NA & $\begin{array}{c}(1) \\
2.686\end{array}$ & $\begin{array}{c}\text { (1) } \\
0.012\end{array}$ & $\begin{array}{c}(6) \\
0.261\end{array}$ & $\begin{array}{c}(3) \\
1.126\end{array}$ \\
\hline Indonesia & $\begin{array}{c}(1) \\
17.764 * *\end{array}$ & $\begin{array}{c}(1) \\
1.448\end{array}$ & $\begin{array}{c}(1) \\
20.093 * *\end{array}$ & $\begin{array}{c}(1) \\
0.252\end{array}$ & $\begin{array}{c}(1) \\
7.334 * *\end{array}$ & $\begin{array}{c}(1)^{* *} \\
8.911^{* *}\end{array}$ & $\begin{array}{c}(1) \\
0.254\end{array}$ & $\begin{array}{c}(1) \\
4.557 * *\end{array}$ \\
\hline Japan & $\begin{array}{c}(2) \\
11.580^{* *}\end{array}$ & $\begin{array}{c}(1) \\
1.957\end{array}$ & $\begin{array}{c}(1) \\
1.327\end{array}$ & $\begin{array}{c}(1) \\
0.288\end{array}$ & $\begin{array}{c}(1) \\
0.600\end{array}$ & $\begin{array}{c}(1) \\
5.405^{* *}\end{array}$ & $\begin{array}{c}(2) \\
8.782 * *\end{array}$ & $\begin{array}{c}(1) \\
9.323^{* *}\end{array}$ \\
\hline Sout & (1) & (2) & (1) & (1) & (3) & (1) & (1) & (1) \\
\hline Malaysia & $\begin{array}{c}(1) \\
9.226^{* *}\end{array}$ & $\begin{array}{c}(1) \\
0.161\end{array}$ & $\begin{array}{c}(1) \\
0.125\end{array}$ & $\begin{array}{c}(1) \\
0.325\end{array}$ & $\begin{array}{l}(1) \\
1.040\end{array}$ & $11.220^{* *}$ & $\begin{array}{c}(1) \\
3.071\end{array}$ & 2.050 \\
\hline Philippines & $\begin{array}{c}(1) \\
1.061\end{array}$ & $\begin{array}{c}(1) \\
0.001\end{array}$ & $\begin{array}{c}(1) \\
1.659\end{array}$ & $\begin{array}{c}(1) \\
1.178\end{array}$ & $\begin{array}{c}(1) \\
0.714\end{array}$ & $\begin{array}{c}(2) \\
4.263 * *\end{array}$ & $\begin{array}{c}(1) \\
2.766\end{array}$ & $\begin{array}{c}(1) \\
4.933^{* *}\end{array}$ \\
\hline Singapore & $\begin{array}{c}(1) \\
1.438\end{array}$ & $\begin{array}{c}(1) \\
0.056\end{array}$ & $\begin{array}{c}(1) \\
0.694\end{array}$ & $\begin{array}{c}(1) \\
1.921\end{array}$ & $\begin{array}{c}(1) \\
13.537^{* *}\end{array}$ & $\begin{array}{c}(1) \\
3.116\end{array}$ & $\begin{array}{c}(1) \\
1.261\end{array}$ & $\begin{array}{c}(1) \\
2.595\end{array}$ \\
\hline Taiwan & $\begin{array}{c}(1) \\
5.303^{* *}\end{array}$ & $\begin{array}{c}(1) \\
2.435\end{array}$ & $\begin{array}{c}(1) \\
1.013\end{array}$ & $\begin{array}{c}(1) \\
3.088\end{array}$ & $\begin{array}{c}(1) \\
0.451\end{array}$ & $\begin{array}{c}(1) \\
0.019\end{array}$ & $\begin{array}{c}(1) \\
4.457 * *\end{array}$ & $\begin{array}{c}(1) \\
0.248\end{array}$ \\
\hline Thailan & $\begin{array}{c}(1) \\
16.897 * *\end{array}$ & $\begin{array}{c}(1) \\
0.359\end{array}$ & $\begin{array}{c}(1) \\
1.797\end{array}$ & $\begin{array}{c}(1) \\
0.443\end{array}$ & $\begin{array}{c}(1) \\
12.842^{* *}\end{array}$ & $\begin{array}{c}(1) \\
0.550\end{array}$ & $\begin{array}{c}(1) \\
5.356^{* *}\end{array}$ & $\begin{array}{c}(1) \\
10.134 * *\end{array}$ \\
\hline
\end{tabular}

Panel B. Second Financial Crisis Index

\begin{tabular}{|c|c|c|c|c|c|c|c|c|}
\hline Markets & $\begin{array}{l}\text { M2/Foreign } \\
\text { Reserve }\end{array}$ & $\begin{array}{l}\text { Lending } \\
\text { Boom/ } \\
\text { GDP }\end{array}$ & $\begin{array}{c}\text { Current } \\
\text { Account/ } \\
\text { GDP }\end{array}$ & $\begin{array}{c}\text { Capital } \\
\text { Account/ } \\
\text { GDP }\end{array}$ & $\begin{array}{l}\text { Foreign } \\
\text { Debt/GDP }\end{array}$ & $\begin{array}{c}\text { Real } \\
\text { Exchange } \\
\text { Rate }\end{array}$ & $\begin{array}{c}\text { Deviation } \\
\text { of PPP }\end{array}$ & $\begin{array}{c}\text { Deviation } \\
\text { of UIP }\end{array}$ \\
\hline China & NA & NA & NA & NA & NA & $\begin{array}{c}(1) \\
0.854\end{array}$ & $\begin{array}{c}(1) \\
1.277\end{array}$ & $\begin{array}{c}(1) \\
0.754\end{array}$ \\
\hline Hong Kong & $\begin{array}{c}(1) \\
3.518\end{array}$ & $\begin{array}{c}(2) \\
0.806\end{array}$ & NA & NA & $\begin{array}{c}(1) \\
0.023\end{array}$ & $\begin{array}{c}(1) \\
0.070\end{array}$ & $\begin{array}{c}(6) \\
2.799\end{array}$ & $\begin{array}{c}(3) \\
0.062\end{array}$ \\
\hline Indonesia & $\begin{array}{c}(1) \\
43.487 * *\end{array}$ & $\begin{array}{c}(1) \\
0.316\end{array}$ & $\begin{array}{c}(1) \\
3.199\end{array}$ & $\begin{array}{c}(1) \\
17.982 * *\end{array}$ & $\begin{array}{c}(1) \\
50.290^{* *}\end{array}$ & $\begin{array}{c}(1) \\
11.403 * *\end{array}$ & $\begin{array}{c}(1) \\
2.916\end{array}$ & $\begin{array}{c}(2) \\
2.623\end{array}$ \\
\hline Japan & $12.290^{* *}$ & $\begin{array}{c}(1) \\
2.027\end{array}$ & $\begin{array}{c}(1) \\
0.092\end{array}$ & $\begin{array}{c}(1) \\
0.331\end{array}$ & $\begin{array}{c}(1) \\
0.717\end{array}$ & $13.812 * *$ & $\begin{array}{c}(2) \\
4.587 * *\end{array}$ & $3.995^{* *}$ \\
\hline $\begin{array}{l}\text { South } \\
\text { Korea }\end{array}$ & $\begin{array}{c}(2) \\
2.555\end{array}$ & $\begin{array}{c}(5) \\
2.277\end{array}$ & $\begin{array}{c}(2) \\
6.260^{* *}\end{array}$ & $\begin{array}{c}(1) \\
0.984\end{array}$ & $\begin{array}{c}(3) \\
5.216^{* *}\end{array}$ & $\begin{array}{c}(1) \\
40.109 * *\end{array}$ & $\begin{array}{c}(2) \\
11.778^{* *}\end{array}$ & $\begin{array}{c}(1) \\
2.692\end{array}$ \\
\hline Malaysia & $15.613^{* *}$ & $\begin{array}{c}(4) \\
1.437\end{array}$ & $\begin{array}{c}(1) \\
2.027\end{array}$ & $\begin{array}{c}(1) \\
1.995\end{array}$ & $\begin{array}{c}(1) \\
1.335\end{array}$ & $\begin{array}{c}(2) \\
15.286 * *\end{array}$ & $\begin{array}{c}(1) \\
4.650^{* *}\end{array}$ & $4.085^{* *}$ \\
\hline Philippines & $\begin{array}{c}(1) \\
24.987 * *\end{array}$ & $\begin{array}{c}(1) \\
0.029\end{array}$ & $\begin{array}{c}(1) \\
0.701\end{array}$ & $\begin{array}{c}(1) \\
0.237\end{array}$ & $\begin{array}{c}(1) \\
0.943\end{array}$ & $\begin{array}{c}(2) \\
6.160^{* *}\end{array}$ & $\begin{array}{c}(2) \\
2.807\end{array}$ & $\begin{array}{c}(1) \\
6.235^{* *}\end{array}$ \\
\hline Singapore & $\begin{array}{c}(1) \\
8.524 * *\end{array}$ & $\begin{array}{c}(1) \\
0.768\end{array}$ & $\begin{array}{c}(1) \\
1.311\end{array}$ & $\begin{array}{c}(1) \\
2.363\end{array}$ & $\begin{array}{c}(1) \\
21.765^{* *}\end{array}$ & $\begin{array}{c}(1) \\
9.702 * *\end{array}$ & $\begin{array}{c}(1) \\
4.368 * *\end{array}$ & $\begin{array}{c}(1) \\
2.607\end{array}$ \\
\hline Taiwan & $\begin{array}{c}(1) \\
5.812^{* * *}\end{array}$ & $\begin{array}{c}(1) \\
0.528\end{array}$ & $\begin{array}{c}(1) \\
1.984\end{array}$ & $\begin{array}{c}(1) \\
0.802\end{array}$ & $\begin{array}{c}(1) \\
3.312\end{array}$ & $\begin{array}{c}(1) \\
1.767\end{array}$ & $\begin{array}{c}(1) \\
1.936\end{array}$ & $\begin{array}{c}(1) \\
0.052\end{array}$ \\
\hline Thailand & $\begin{array}{c}(6) \\
5.104 * *\end{array}$ & $\begin{array}{c}(2) \\
1.866\end{array}$ & $\begin{array}{c}(1) \\
4.170^{* *}\end{array}$ & $\begin{array}{c}(1) \\
0.839\end{array}$ & $\begin{array}{c}(1) \\
2.757\end{array}$ & $\begin{array}{c}(1) \\
7.727 * *\end{array}$ & $\begin{array}{c}(1) \\
5.361 * *\end{array}$ & $\begin{array}{c}(1) \\
11.966^{* * *}\end{array}$ \\
\hline
\end{tabular}

** denotes $5 \%$ significant level. NA means that data is not available. 
Reinhart (1996), and Sachs et al. (1996). However, the increased M2/foreign reserve may be the result of capital inflows provided the central bank did not sterilize intervention. Meanwhile, the foreign debt/GDP may result from the deviation of UIP. Hence, we cannot rule out the possibility of spurious relation.

\subsection{Vector autoregression (VAR) causality test}

Granger causality tests can identify several factors that should be important in the causing the financial crisis, but it may suffer from the problem of spurious relation. To overcome this problem, we use the VAR causality test to investigate which factors are important to the origins of the financial crisis. VAR causality is a multivariate generalization of Granger causality test. The VAR model is:

$$
\Delta y_{t}=\mu+\Gamma_{1} \Delta y_{t-1}+\cdots+\Gamma_{p} \Delta y_{t-p}+\zeta_{t},
$$

where $y_{t}$ are the explanatory variables and financial crisis index, $\mu$ is a vector of constant terms, $\Gamma_{i}$ is the matrix of parameters, and $\zeta_{t}$ is a vector of error terms. We test the null hypothesis that the coefficients of one set variable do not reach significant level to effect the financial crisis.

Table 5 displays the results of testing VAR causality for the financial crisis indices. ${ }^{5}$ Panel A shows the results of examining the first financial crisis index, while panel B shows the results of examining the second financial crisis index. For Indonesia's first financial crisis index, a significant variable (foreign debt/GDP) in Granger causality test is no longer significant in VAR causality test. Only M2/foreign reserve, current account/GDP, and real exchange rate, and deviations of PPP could explain the first financial crisis index. The variables that affect Indonesia's second financial crisis index are very similar to the first. They are M2/foreign reserve, current account/GDP, capital account/GDP, and deviations of PPP.

In Japan, no variable could cause the first and second financial crisis indices at a conventional significant level. The significant variables (M2/foreign reserve, real exchange rate, and deviations of PPP and UIP) in Granger causality tests do not reach conventional significant level any more.

In South Korea, M2/foreign reserve and lending boom/GDP affect the first financial crisis index significantly. However, the second financial crisis index cannot be explained by all the variables we examined.

\footnotetext{
${ }^{5}$ The whole results of VAR test are available upon the request.
} 
Table 5. Vector Autoregression Causality Tests

We test the null hypothesis that the coefficients of one variable does not reach significant level to the financial crisis index. Lags are chosen by statistics $(T-k)\left(\log \left|D_{R}\right|-\log \left|E_{u}\right|\right)$, which converge to chi-square distribution with degrees of freedom equal to the number of constrained parameters. In the likelihood ratio statistic, $T$ is the sample size, $k$ is the total number of regression coefficients estimated divided by the number of equations, $D_{R}$ and $D_{U}$ are the matrices of cross products of residuals of restricted and unrestricted model respectively, and $|\bullet|$ is a determinant function. While the list of marcoeconomic variables in Hong Kong is too short to obtain reliable estimates, the data of gross domestic production in China and Malaysia are also not enough to get a robust estimate.

Panel A. First Financial Crisis Index

\begin{tabular}{|c|c|c|c|c|c|c|c|c|c|c|}
\hline Markets & Lags & $\begin{array}{c}\text { M2/Foreign } \\
\text { Reserve }\end{array}$ & $\begin{array}{l}\text { Lending } \\
\text { Boom/ } \\
\text { GDP }\end{array}$ & $\begin{array}{l}\text { Current } \\
\text { Account/ } \\
\text { GDP }\end{array}$ & $\begin{array}{l}\text { Capital } \\
\text { Account/ } \\
\text { GDP }\end{array}$ & $\begin{array}{c}\text { Foreign } \\
\text { Debt/GDP }\end{array}$ & $\begin{array}{c}\text { Real } \\
\text { Exchange } \\
\text { Rate }\end{array}$ & $\begin{array}{c}\text { Deviation } \\
\text { of PPP }\end{array}$ & $\begin{array}{c}\text { Deviation } \\
\text { of UIP }\end{array}$ & $\begin{array}{c}\text { First } \\
\text { financial } \\
\text { crisis index }\end{array}$ \\
\hline China & NA & NA & NA & NA & NA & NA & NA & NA & NA & NA \\
\hline Hong Kong & NA & NA & NA & NA & NA & NA & NA & NA & NA & NA \\
\hline Indonesia & 1 & $7.457^{* *}$ & 0.030 & $25.063^{* *}$ & 3.193 & 1.016 & $5.732^{* *}$ & $5.044^{* *}$ & 3.109 & 2.049 \\
\hline Japan & 4 & 0.282 & 0.360 & 1.230 & 2.003 & 0.848 & 0.928 & 0.252 & 0.138 & $4.327^{* *}$ \\
\hline South Korea & 4 & $3.052^{* *}$ & $2.677^{* *}$ & 0.914 & 1.657 & 2.093 & 0.335 & 0.740 & 0.202 & 1.308 \\
\hline Malaysia & NA & NA & NA & NA & NA & NA & NA & NA & NA & NA \\
\hline Philippines & 4 & 0.571 & $3.805^{* *}$ & 2.529 & 2.796 & 0.237 & 1.576 & 1.953 & $4.128^{* *}$ & 2.638 \\
\hline Singapore & 4 & 1.267 & 0.914 & 1.674 & 1.260 & 1.149 & 0.808 & 0.761 & 0.392 & $3.671^{* *}$ \\
\hline Taiwan & 1 & $4.726^{* *}$ & 1.814 & 0.163 & $7.173^{* *}$ & 2.846 & 0.287 & $7.857^{* *}$ & 3.894 & $5.799^{* *}$ \\
\hline Thailand & 1 & $5.822^{* *}$ & 3.120 & $3.514^{*}$ & 1.241 & $4.755^{* *}$ & 2.307 & 0.001 & 0.637 & 2.670 \\
\hline
\end{tabular}


Table 5. (continued) Vector Autoregression Causality Tests

Panel B. Second Financial Crisis Index

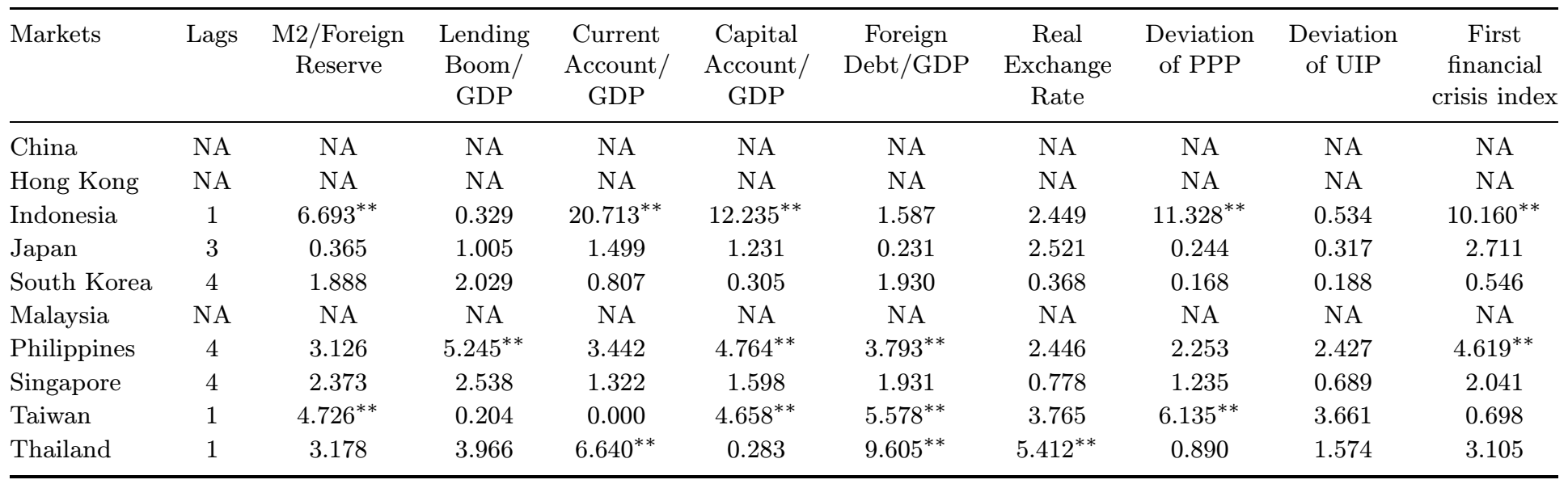

${ }^{* *}$ denotes $5 \%$ significant level. NA means that data is not available. 
Lending boom/GDP and deviations of UIP can help to explain the first financial crisis index in the Philippines, while lending boom/GDP, capital account/GDP, and foreign debt/GDP help to explain the second financial crisis index.

No variable which we examined can explain Singapore's first and second financial crisis index significantly. The results are contrary to the results of Granger causality test, because the significant variables (M2/foreign reserve, foreign debt/GDP, real exchange rate, and deviations of PPP) in Granger causality test are no longer significant.

The variables that help to explain Taiwan's first financial crisis index are M2/foreign reserve, capital account/GDP, and the deviations of PPP. Meanwhile, M2/foreign reserve, capital account/GDP, foreign debt/GDP, and the deviations of PPP also Granger-cause Taiwans second financial crisis index. The difference between these two results is that foreign debt/GDP is only significant in the second financial crisis index.

The M2/foreign reserve and foreign debt/GDP help to explain Thailand's first financial crisis index. However, the variables that cause the second financial crisis index are not the same as the first one. The significant variables are current account/GDP, foreign debt/GDP, and real exchange rate.

In general, the coefficients do not lead to strong conclusions about cause relation between most explanatory variables and the financial crisis indices. However, all coefficients are predominantly positive. The VAR causality test reduces the possibility of spurious relation. However, it raises the problem of multicollinearity. The number of parameters is also exaggerated, resulting in insignificant estimates. This is the reason why the significant estimates in VAR causality test are less than those in Granger causality test.

Accordingly, we use block exogeneity test to examine the influences of both deviations of PPP and UIP on the financial crisis index and other macroeconomic variables. We first estimate the following equation:

$$
\Delta y_{t}=\mu+\Gamma_{1} \Delta y_{t-1}+\cdots+\Gamma_{p} \Delta y_{t-p}+\Theta_{1} \Delta x_{t-1}+\cdots+\Theta_{p} \Delta x_{t-p}+v_{t}
$$

where $y_{t}$ include M2/foreign reserve, lending boom/GDP, current account/GDP, capital account/GDP, foreign debt/GDP, real exchange rate, and the financial crisis index. $\mu$ is a vector of constants. $\Gamma_{i}$ is $7 \times 7$ matrix of parameters, and $\Theta_{j}$ is $7 \times 2$ matrix of parameters. $x_{t}$ contains deviations of PPP and UIP, and $v_{t}$ is a vector of error terms. 
If deviations of PPP and UIP do not Granger-cause other macroeconomic variables and the financial crisis index, the estimates of parameter $\Theta_{j}$ should be equal to zero significantly. Sims (1980) suggested using likelihood ratio test to examine the null hypothesis of zero estimates of parameter $\Theta_{j}$. Therefore, we estimate the following constrained equation:

$$
\Delta y_{t}=\mu+\Gamma_{1} \Delta y_{t-1}+\cdots+\Gamma_{p} \Delta y_{t-p}+\xi_{t},
$$

where $\xi_{t}$ is also a vector of error terms. Then, we compute the likelihood ratio statistic: $(T-k)\left(\log \left|D_{R}\right|-\log \left|D_{U}\right|\right)$, which converge to chi-square $\left(\chi^{2}\right)$ distribution with degrees of freedom equal to the number of constrained parameters. In the likelihood ratio statistic, $T$ is the sample size, $k$ is the total number of estimated regression coefficients divided by the number of equations, $D_{R}$ and $D_{U}$ are the matrix of cross products of residuals of restricted and unrestricted model respectively, and $|\bullet|$ is a determinant function.

Table 6 shows the results. The macroeconomic variables and the first financial crisis index are influenced significantly by the deviation of PPP in Japan and Thailand. However, the deviations of UIP only impacts Japan's macroeconomic variables and first financial crisis index significantly. When we combine these two deviations, only Japan reaches a $5 \%$ significant level. For the second financial crisis index, the deviations of PPP significantly affects macroeconomic variables and the second financial crisis index in Indonesia, Japan, the Philippines, and Thailand. The deviations of UIP significantly cause the macroeconomic variables and the second financial crisis index of Japan and Thailand. When we combine these two deviations, there are four markets macroeconomic variables and second financial crisis indices that are caused by these two deviations. They are Indonesia, Japan, the Philippines and Thailand.

Although block exogeneity test cannot directly detect the Granger causality of the deviations of PPP and UIP to the financial crisis, it can measure the influence of these two deviations on the macroeconomic variables and financial crisis. Moreover, many studies have shown that the financial crisis is caused by macroeconomic variables such as M2, lending boom, current account, capital account, foreign debt, and real exchange rate. If the deviations of PPP and UIP have power to explain these macroeconomic variables, we need to pay attention to these two deviations to prevent future financial crisis. 
Table 6. Block Exogeneity Tests

We conduct a likelihood ratio statistic: $(T-k)\left(\log \left|D_{R}\right| \log \left|D_{U}\right|\right)$, which converge to chisquare distribution with degrees of freedom equal to the number of constrained parameters. In the likelihood ratio statistic, $T$ is the sample size, $k$ is the total number of regression coefficients estimated divided by the number of equations, $D_{R}$ and $D_{U}$ are the matrix of cross products of residuals of restricted and unrestricted model respectively, and $|\bullet|$ is determinant function. While the list of macroeconomic variables in Hong Kong is too short to obtain a reliable estimate, the data of gross domestic production in China and Malaysia are also not enough to get a robust estimate.

\begin{tabular}{lccccccc}
\hline & \multicolumn{4}{c}{ First financial crisis index } & \multicolumn{3}{c}{ Second financial crisis index } \\
\hline Markets & $\begin{array}{c}\text { Lags } \\
\text { Deviation } \\
\text { of PPP }\end{array}$ & $\begin{array}{c}\text { Deviation } \\
\text { of UIP }\end{array}$ & $\begin{array}{c}\text { Deviation of Deviation } \\
\text { Both PPP } \\
\text { and UIP }\end{array}$ & $\begin{array}{c}\text { Deviation PPP } \\
\text { of UIP }\end{array}$ & $\begin{array}{c}\text { Deviation of } \\
\text { Both PPP } \\
\text { and UIP }\end{array}$ \\
\hline China & NA & NA & NA & NA & NA & NA & NA \\
Hong Kong & NA & NA & NA & NA & NA & NA & NA \\
Indonesia & 1 & 7.686 & 5.788 & 18.477 & $28.271^{* *}$ & 9.207 & $34.352^{* *}$ \\
Japan & 4 & $42.617^{* *}$ & $40.587^{* *}$ & $64.254^{* *}$ & $65.491^{* *}$ & $66.780^{* *}$ & $90.652^{* *}$ \\
South Korea & 4 & 27.674 & 15.543 & 50.945 & 35.809 & 19.317 & 60.361 \\
Malaysia & NA & NA & NA & NA & NA & NA & NA \\
Philippines & 1 & 7.477 & 5.150 & 13.763 & $17.750^{* *}$ & 10.346 & $23.689^{* *}$ \\
Singapore & 4 & 12.594 & 13.696 & 23.327 & 15.634 & 18.063 & 27.200 \\
Taiwan & 1 & 12.461 & 9.455 & 21.938 & 10.607 & 10.354 & 22.794 \\
Thailand & 3 & $34.940^{* *}$ & 26.575 & 51.014 & $44.783^{* *}$ & $40.097^{* *}$ & $63.542^{* *}$ \\
\hline
\end{tabular}

${ }^{* *}$ denotes $5 \%$ significant level. NA means that data is not available.

\section{Conclusions}

Most of the empirical studies on the 1997 Asian financial crisis focus on the influence of some macroeconomic variables. In this study, we emphasize the deviations of PPP and UIP to clarify the 1997 Asian financial crisis. To test our hypothesis, we use vector autoregression and Granger causality test to examine whether these two deviations Granger-cause the Asian financial crisis. The result shows that the PPP and UIP do not hold for most Asian markets. We find weak evidences that the deviations of PPP and UIP have the power to explain the origin of the Asian financial crisis.

The results suggest that the exchange rate will not fully reflect the differentials of a home inflation rate and interest rate with respect to other countries under fixed or pegged exchange rate regime. The deviations of PPP and UIP would positively affect demand for investing in the Asian markets, leading to large variations of capital flow in a more integrated financial market. The more rapid growth of the variations of capital flow would affect the level of domestic macroeconomic variables, which in turn trigger the financial crisis. 


\section{Appendix. Data Source and Unit Root Test}

Most of data come from International Financial Statistics (IFS) of International Monetary Fund (IMF). Only exchange rate comes from FOREX database. Meanwhile, Taiwan is not a member of IMF, so Taiwan's data comes from the IMF IFS format financial statistics database of AREMOS/UNIX Taiwan Econimic Statistical Databank System. The detailed data source, period, and code are shown in Table A1. The data of current account and capital account in Hong Kong are not available. In addition, the data of gross domestic product in China and Malaysia are too short to be examined.

Table A2 displays the results of testing unit root for financial crisis indices and macroeconomic variables. For M2/foreign reserve, only Japan rejects the existence of unit root. The countries that can not reject the existences of unit root of current account/GDP are South Korea and Malaysia. There are three countries that reject the unit root test of capital account/GDP. These are Malaysia, the Philippines, and Taiwan. In the lending boorn/GDP, only the Philippines rejects the unit root test. There are not any country that can reject the unit root tests of foreign debt/GDP and real exchange rate. Three country's deviations of PPP reject the existences of unit root. These are Hong Kong, Indonesia, and Taiwan. All the deviations of UIP cannot reject the unit root tests. All the countries we examined reject the null hypothesis of a unit root for financial crisis indices, neither first nor second.

Table A1. Data Source and Period*

\begin{tabular}{lccccc}
\hline \multicolumn{1}{c}{ Market } & $\begin{array}{c}\text { Exchange } \\
\text { rate }\end{array}$ & Interest rate & $\begin{array}{c}\text { Foreign } \\
\text { reserve }\end{array}$ & $\begin{array}{c}\text { Consumer } \\
\text { price index }\end{array}$ & Money supply \\
\hline China & $70: 1 \sim 98: 2$ & $80: 1 \sim 98: 2$ & $78: 1 \sim 98: 2$ & $92: 1 \sim 98: 2$ & $78: 1 \sim 98: 2$ \\
Hong Kong & $70: 1 \sim 98: 2$ & $90: 4 \sim 98: 2$ & $90: 4 \sim 98: 2$ & $90: 1 \sim 98: 2$ & $91: 4 \sim 98: 2$ \\
Indonesia & $70: 1 \sim 98: 2$ & $78: 1 \sim 98: 2$ & $70: 1 \sim 98: 2$ & $70: 1 \sim 98: 2$ & $70: 1 \sim 98: 2$ \\
Japan & $70: 1 \sim 98: 2$ & $70: 1 \sim 98: 2$ & $70: 1 \sim 98: 2$ & $70: 1 \sim 98: 2$ & $70: 1 \sim 98: 2$ \\
South Korea & $70: 1 \sim 98: 2$ & $70: 1 \sim 98: 2$ & $70: 1 \sim 98: 2$ & $70: 1 \sim 98: 2$ & $70: 1 \sim 98: 2$ \\
Malaysia & $70: 1 \sim 98: 2$ & $70: 1 \sim 98: 2$ & $70: 1 \sim 98: 2$ & $70: 1 \sim 98: 2$ & $70: 1 \sim 98: 2$ \\
Philippines & $70: 1 \sim 98: 2$ & $76: 1 \sim 98: 2$ & $70: 1 \sim 98: 2$ & $70: 1 \sim 98: 2$ & $70: 1 \sim 98: 2$ \\
Singapore & $70: 1 \sim 98: 2$ & $70: 1 \sim 98: 2$ & $70: 1 \sim 98: 2$ & $70: 1 \sim 98: 2$ & $70: 1 \sim 98: 2$ \\
Taiwan & $80: 1 \sim 98: 2$ & $80: 11 \sim 98: 2$ & $80: 1 \sim 98: 2$ & $80: 1 \sim 98: 2$ & $80: 1 \sim 98: 2$ \\
Thailand & $70: 1 \sim 98: 2$ & $70: 1 \sim 98: 2$ & $70: 1 \sim 98: 2$ & $70: 1 \sim 98: 2$ & $70: 1 \sim 98: 2$ \\
Source & FOREX & IFS & IFS & IFS & IFS \\
Code & M***REX & L60b & L11 & L64 & L34+L35 \\
\hline
\end{tabular}


Table A1. (continued) Data Source and Period*

\begin{tabular}{lccccc}
\hline \multicolumn{1}{c}{ Market } & $\begin{array}{c}\text { Current } \\
\text { account }\end{array}$ & $\begin{array}{c}\text { Capital } \\
\text { account }\end{array}$ & $\begin{array}{c}\text { Lending } \\
\text { boom }\end{array}$ & Foreign debt & $\begin{array}{c}\text { Gross } \\
\text { dome-site } \\
\text { product }\end{array}$ \\
\hline China & $82: 1 \sim 98: 2$ & $82: 1 \sim 98: 2$ & $78: 1 \sim 98: 2$ & $77: 4 \sim 98: 2$ & $92: 1 \sim 98: 2$ \\
Hong Kong & NA & NA & $90: 4 \sim 98: 2$ & $91: 2 \sim 98: 2$ & $73: 1 \sim 98: 2$ \\
Indonesia & $81: 1 \sim 98: 2$ & $81: 1 \sim 98: 2$ & $70: 1 \sim 98: 2$ & $70: 1 \sim 98: 2$ & $70: 1 \sim 98: 2$ \\
Japan & $77: 1 \sim 98: 2$ & $85: 1 \sim 98: 2$ & $70: 1 \sim 98: 2$ & $70: 1 \sim 98: 2$ & $70: 1 \sim 98: 2$ \\
South Korea & $76: 1 \sim 98: 2$ & $76: 1 \sim 98: 2$ & $70: 1 \sim 98: 2$ & $70: 1 \sim 98: 2$ & $70: 1 \sim 98: 2$ \\
Malaysia & $70: 1 \sim 98: 2$ & $70: 1 \sim 98: 2$ & $70: 1 \sim 98: 2$ & $70: 1 \sim 98: 2$ & $88: 1 \sim 95: 4$ \\
Philippines & $70: 1 \sim 98: 2$ & $70: 1 \sim 98: 2$ & $70: 1 \sim 98: 2$ & $70: 1 \sim 98: 2$ & $70: 1 \sim 98: 2$ \\
Singapore & $70: 1 \sim 98: 2$ & $70: 1 \sim 98: 2$ & $70: 1 \sim 98: 2$ & $70: 1 \sim 98: 2$ & $84: 1 \sim 98: 2$ \\
Taiwan & $80: 1 \sim 98: 2$ & $80: 1 \sim 98: 2$ & $94: 1 \sim 98: 2$ & $94: 1 \sim 98: 2$ & $80: 1 \sim 98: 2$ \\
Thailand & $70: 1 \sim 98: 2$ & $70: 1 \sim 98: 2$ & $70: 1 \sim 98: 2$ & $70: 1 \sim 98: 2$ & $70: 1 \sim 98: 2$ \\
Source & IFS & IFS & IFS & IFS & IFS \\
Code & L78ald & L78bcd+L78 & L23d & L16c+L26c & L99b \\
& & bid+L78cad & & & \\
\hline
\end{tabular}

${ }^{*}$ The exchange rates come from the FOREX, which is monthly frequency. We tranfrom the monthly data to quarterly data by geometric average. The data of Taiwan comes from the IMF IFS format financial statistics database of AREMOS/UNIX Taiwan Economic Statistical Databank System. NA denotes that data is not available.

Table A2. Unit Root Tests of Financial Crisis Indices and Macroeconomic Variables*

\begin{tabular}{llllll}
\hline \multicolumn{1}{c}{ Market } & $\begin{array}{l}\text { M2/Foreign } \\
\text { Reserve }\end{array}$ & $\begin{array}{c}\text { Current } \\
\text { Account/GDP }\end{array}$ & $\begin{array}{c}\text { Capital } \\
\text { Account/GDP }\end{array}$ & $\begin{array}{c}\text { Lending } \\
\text { Boom/GDP }\end{array}$ & $\begin{array}{c}\text { Foreign } \\
\text { Debt/GDP }\end{array}$ \\
\hline China & NA & NA & NA & NA & NA \\
Hong Kong & $(0)-1.978$ & NA & NA & $(4)-2.264$ & $(0)-3.290$ \\
Indonesia & $(1)-0.235$ & $(0)-5.022^{* *}$ & $(0)-2.740$ & $(4)-1.274$ & $(1)-0.720$ \\
Japan & $(4)-3.465 * *$ & $(4)-3.678^{* *}$ & $(1)-3.106$ & $(4)-2.192$ & $(4)-2.720$ \\
South Korea & $(4)-2.312$ & $(0)-3.00$ & $(1)-2.593$ & $(4)-2.094$ & $(4)-2.498$ \\
Malaysia & $(3)-0.757$ & $(3)-0.405$ & $(3)-5.169^{* *}$ & $(3)-0.487$ & $(3)-1.031$ \\
Philippines & $(20) 2.310$ & $(0)-4.176^{* *}$ & $(0)-7.096^{* *}$ & $(20)-3.292^{* *}$ & $(4)-0.269$ \\
Singapore & $(0)-2.260$ & $(1)-5.076$ & $(9)-2.554$ & $(15)-0.850$ & $(0)-2.836$ \\
Taiwan & $(1)-1.638$ & $(0)-3.873^{* *}$ & $(0)-5.584^{* *}$ & $(18)-0.874$ & $(20)-0.788$ \\
Thailand & $(5)-1.377$ & $(0)-3.474^{* *}$ & $(1)-0.118$ & $(1)-2.057$ & $(9)-5.682$ \\
\hline
\end{tabular}


Table A2. (continued) Unit Root Tests of Financial Crisis Indices and Macroeconomic Variables*

\begin{tabular}{lccccc}
\hline \multirow{1}{*}{ Market } & $\begin{array}{c}\text { Real Exchange } \\
\text { Rate }\end{array}$ & $\begin{array}{c}\text { Deviation of } \\
\text { PPP }\end{array}$ & $\begin{array}{c}\text { Deviation of } \\
\text { UIP }\end{array}$ & $\begin{array}{c}\text { First financial } \\
\text { crisis index }\end{array}$ & $\begin{array}{c}\text { Second financial } \\
\text { crisis index }\end{array}$ \\
\hline China & $(0)-2.939$ & $(20)-3.254$ & $(0) 0.665$ & $(0)-5.504^{* *}$ & $(0)-7.403^{* *}$ \\
Hong Kong & $(0)-0.903$ & $(0)-3.849$ & $(1)-0.607$ & $(2)-3.789$ & $(0)-6.341^{* *}$ \\
Indonesia & $(1)-1.306$ & $(0)-4.633^{* *}$ & $(0)-8.373^{* *}$ & $(0)-8.373^{* *}$ & $(0)-8.873$ \\
Japan & $(1)-2.465$ & $(2)-1.522$ & $(1)-1.857$ & $(0)-8.726$ & $(0)-7.996$ \\
South South & $(3)-1.644$ & $(2)-1.150$ & $(3)-0.081$ & $(0)-6.966^{* *}$ & $(3)-528^{* *}$ \\
Malaysia & $(1)-3.081$ & $(3)-0.841$ & $(2)-1.675$ & $(0)-6.836^{* *}$ & $(0)-6.379^{* *}$ \\
Philippines & $(0)-1.969$ & $(1)-1.429$ & $(2)-0.440$ & $(0)-7.943^{* *}$ & $(0)-8.574^{* *}$ \\
Singapore & $(1)-2.477$ & $(3)-0.033$ & $(1)-2.127$ & $(0)-7.743^{* *}$ & $(0)-8.206^{* *}$ \\
Taiwan & $(0)-1.263$ & $(0)-4.117^{* *}$ & $(1)-1.311^{* *}$ & $(20)-15.63^{* *}$ & $(0)-4.663^{* *}$ \\
Thailand & $(3)-2.089$ & $(3)-0.509$ & $(3)-0.167$ & $(0)-6.966^{* *}$ & $(0)-7.602^{* *}$ \\
\hline
\end{tabular}

${ }^{*}$ The unit root tests are conducted by Augmented Dickey-Fuller (ADF) test with constant and trend. The choice of lags is based on BIC criteria. This routine is written by Norman Morin, and is posted on Estima web site. We response for any errors. ${ }^{* *}$ mean $5 \%$ significant level.

\section{References}

Basile, A. and J. P. Joyce, "Asset Bubbles, Monetary Policy and Bank Lending in Japan", Wellseley College Working Paper 98-10 (August 1998).

Bayoumi, T. and MacDonald, R., "Deviations of Exchange Rates from Purchasing Power Parity: A Story Featuring Two Monetary Unions", IMF Staff Papers 46, 89-102 (March 1999).

Chinn, M. D., "Before the Fall: Were East Asian Currencies Overvalued?" National Bureau of Economic Research Working Paper 6491 (April 1998).

Chinn, M. D. and J. A. Frankel, "Who Drives Real Interest Rates around the Pacific Rim: The USA or Japan?", Journal of International Money and Finance 14, 801-821 (1995).

Cole, H. L. and T. J. Kehoe, "A Self-fulfilling Model of Mexico's 1994-95 Debt Crisis", Federal Reserve Bank of Minneapolis, Research Department Staff Report 210 (April 1996).

Cole, H. L. and T. J. Kehoe, "Self-fulfilling Debt Crisis", Federal Reserve Bank of Minneapolis, Research Department Staff Report 211 (July 1998).

Corsetti, G., P. Pesenti, and N. Roubini, "What Caused the Asian Currency and Financial Crisis? Part I: A Macroeconomic Overview", National Bureau of Economic Research, Working Paper 6833 (September 1998a).

Corsetti, G., P. Pesenti, and N. Roubini, "Paper Tigers? A Model of the Asian Crisis", National Bureau of Economic Research, Working Paper 6783 (September 1998b).

Edison, H. J., P. Luangaram, and M. Miller, "Asset Bubbles, Domino Effects and Lifeboats: Elements of the East Asian Crisis", Board of Governors of the Federal Reserve System, International Finance Discussion Papers 606 (March 1998). 
Edwards, S., "Currency Crises and Collapses: Comments and Discussion", Brookings Papers on Economic Activity 2, 271-278 (1995).

Edwards, S., "On Crisis Prevention: Lessons from Mexico and East Asia", National Bureau of Economic Research, Working Paper 7233 (July 1999).

Folkerts-Landau, D. and T. Ito, "International Capital Markets: Developments, Prospects, and Policy Issues", Washington, D. C., International Monetary Fund (1995).

Frankel, J. A. and C. Okongwu, "Liberalized Portfolio Capital Inflows in Emerging Markets: Sterilization, Expectations, and the Incompleteness of Interest Rate Convergence", National Bureau of Economic Research, Working Paper 5156 (June 1995).

Frankel, J. A. and A. K. Rose, "Currency Crashes in Emerging Markets: An Empirical Treatment", Journal of International Economics 4, 351-366 (1996).

Goodwin, B. K. and T. J. Grennes, "Real Interest Rate Equalization and the Integration of International Financial Markets", Journal of International Money and Finance 13, 107-124 (1994).

Kaminsky, G. and C. M. Reinhart, "The Twin Crises: The Causes of Banking and Balance-of-Payments Problems", Board of Governors of the Federal Reserve System, International Finance Discussion Paper, No. 544 (March 1996).

Kaminsky, G., S. Lizondo, and C. M. Reinhart, "Leading Indicators of Currency Crises", IMF Staff Papers 45, 1-48 (March 1998).

Nixson, F. I. and B. Walters, "The Asian Crisis: Causes and Consequences", The Manchester School 67, 497-523 (1999).

Obstfeld, M. and K. Rogoff, "The Mirage of Fixed Exchange Rates", Journal of Economic Perspectives 9, 73-96 (Fall 1995).

Radelet, S. and J. Sachs, "The East Asian Financial Crisis: Diagnosis, Remedies, Prospects", Brookings Papers on Economic Activity 5, 1-90 (1998a).

Radelet, S. and J. Sachs, "The Onset of the East Asian Financial Crisis", National Bureau of Economic Research, Working Paper 6680 (August 1998b).

Sachs, J. D., A. Tornell, and A. Velasco, "Financial Crises in Emerging Markets: The Lessons from 1995", Brookings Papers on Economic Activity 3, 147-215 (1996).

Sims, C., "Macroeconomics and Reality", Econometrica 48, 1-48 (January 1980). 